\title{
Review
}

\section{New Strategies in the Prevention of Actinic Keratosis: A Critical Review}

\author{
Jean Krutmann ${ }^{a, b}$ Carola Berking ${ }^{c}$ Mark Berneburg ${ }^{d}$ Thomas L. Diepgen $^{e}$ \\ Thomas Dirschka $^{f}$ Markus Szeimies ${ }^{9}$ \\ a IUF - Leibniz Research Institute for Environmental Medicine, and b Medical Faculty, Deanery of Medicine, University \\ of Düsseldorf, Düsseldorf, 'CClinic and Policlinic for Dermatology and Allergology, Ludwig Maximilian University \\ of Munich (LMU), Munich, dDepartment of Dermatology, University of Regensburg, Regensburg, e Department of \\ Clinical Social Medicine, Occupational and Environmental Medicine, University Hospital Heidelberg, Heidelberg, \\ ${ }^{f}$ Dermatologic Practice Center, Wuppertal, and ${ }^{9}$ Department of Dermatology and Allergology, Vest Clinic, \\ Recklinghausen, Germany
}

\section{Key Words}

Actinic keratosis · Nonmelanoma skin cancer · Photolyase ·

Medical device $\cdot$ Photoprotection · Photorepair

\section{Abstract}

Actinic keratosis (AK) or lesions of epidermal dysplasia occurring in skin chronically exposed to solar radiation is very prevalent in lighter skin persons, with chronic long-term sun exposure being the major risk factor. With an aging population it is expected that the prevalence of AK will further increase. AK can progress to nonmelanoma skin cancer (NMSC) and is a public health concern. Six leading dermatologists with expertise in AK and NMSC from Germany met to discuss the nature of the disease and the prevention and treatment strategies available to dermatologists today. While cosmetic sunscreen products form an essential element of sun protection strategies, they are not adequate when damage has already been inflicted. Newly developed products of the medical device category offer DNA repair function paired with high sun protection factor (SPF) UV protection. An adjuvant treatment algorithm for various risk levels of AK was developed. For patients with low and moderate risk, sunscreen only is recommended. For patient groups with high and very high risk, a very high photoprotection and photorepair action (DNA repair enzymes) in medical device products all year round is recommended.

(c) 2015 S. Karger AG, Basel

\section{Introduction}

Actinic keratosis $(\mathrm{AK})$ is a common skin disease characterized by lesions of epidermal dysplasia appearing on skin chronically exposed to solar radiation such as the head, scalp, face, forearms, and backs of the hands, primarily in persons with Fitzpatrick skin types I, II and III. In Australia, AK is found in $40-50 \%$ of the Caucasian population over the age of 40 years [1] and reported as $40-60 \%$ by Frost and Green [2]. The prevalence in the USA ranges from 11 to 26\% [3], whilst in Europe 15\% of men and $6 \%$ of women have been reported to be affected [3]. In Germany a recent study estimated the standardized prevalence of AK from dermatological examinations at $2.7 \%$, with prevalence increasing with age $(11.5 \%$ in the group 60-70 years) [4]. The prevalence, which is at the

\section{KARGER 125}

C 2015 S. Karger AG, Basel

$1660-5527 / 15 / 0286-0281 \$ 39.50 / 0$ 
lower limit of studies from other countries, suggests about 1.7 million estimated AK cases documented by dermatologists in Germany. In 2011, AK accounted for 8.3\% of the 100 most frequently treated dermatological outpatient diagnoses in Germany, with the proportion of AK cases rising almost continuously over the last 10 years compared to other dermatological conditions [4]. Chronic long-term sun exposure is the major risk factor for $\mathrm{AK}$ [5]. In Germany, the medical consultation board of 'occupational diseases' of the Ministry of Labor and Social affairs has investigated the association between occupational UV irradiation and skin cancer risk. Recently, the following new occupational disease was added to appendix 1 of the German ordinance on occupational diseases (Berufskrankheitenverordnung, BKV): 'squamous cell carcinoma and multiple actinic keratosis due to natural UV irradiation' [6]. Published epidemiological studies show that cumulative occupational exposure is a substantial and robust risk factor for the development of cutaneous squamous cell carcinoma (SCC) [7]. These findings are of significant public health impact as they highlight the need for preventive measures for individuals with high levels of work-related UV radiation exposure [7]. Outdoor workers, as in agriculture, forestry, seafaring, construction, and road maintenance, have a greater occupational exposure to UV. An additional occupational UV exposition of $40 \%$ is assumed to double the risk of skin cancer and is thus legally relevant for the pathogenesis of an occupational disease [6].

Because of the current demographic development it is expected that the incidence of AK will further increase. Furthermore, $\mathrm{AK}$ is chronic and recurrent in nature, with immunosuppressed patients at an even greater risk for developing nonmelanoma skin cancer (NMSC). Thus, it is a significant economic burden for health care systems. As a consequence there is a growing need for the development of novel preventive strategies. With this as background, six experts, all dermatologists, with expertise in photodermatology, dermatooncology and dermatoepidemiology, met to form an expert panel. Panel members were from various German hospitals, university hospitals and/or private practice. During the meeting, these experts worked on the formalization and writing of this report, which was based mainly on the existing literature as well as their own practice and experience. The topics discussed were the molecular basis of $\mathrm{AK}$, progression to SCC of AK, risk factors for $\mathrm{AK}$, and existing options for the prevention of $\mathrm{AK}$. In particular, recently published literature about the efficacy of medical devices was reviewed.

\section{Molecular Events in AK Initiation and AK-to-SCC Progression}

Actinically damaged skin has an accumulation of oncogenic mutations leading to a proliferation of atypical keratinocytes that may manifest as AK or SCC [8]. Underlying molecular changes in normal-appearing skin, detectable by histology or immunohistochemistry, are present before any clinical changes can be observed. The pathophysiology associated with UV-damaged skin demonstrates that $\mathrm{AK}$ is one of the initial events in a disease progression that can ultimately lead to invasive SCC. In this context the term field cancerization is important. Field cancerization is defined as a biological process in which large areas of cells at a tissue surface or within an organ are affected by carcinogenic alterations [9]. The process arises from exposure to an injurious environment, often over a lengthy period. In the case of AK, field cancerization specifically refers to the process whereby keratinocytes surrounding the visible lesion are genetically altered but appear histologically normal. In other words, field cancerization is related to cells with cancerassociated genetic alterations but without invasive growth [10]. The preneoplastic phase in skin is likely to reflect an accumulation of mutations that form the basis for the carcinogenesis process. Recurrence is more or less designated to the (clinical/histological) reappearance of remnant tumor nests which then form again as a visible (clinically evident) tumor. When a tumor is excised from a predisposed epidermis, recurrence may occur. This may be due to neoplastic conversion of residual parts of field cancerization or, more likely, to the fact that adjacent areas with the same extent of UV exposure which exhibit the same amount and quality of mutagenic 'hits' as the already evolved $\mathrm{AK}$ also develop visible $\mathrm{AK}$, which by definition is then a 'de novo' genesis but in a fieldcancerized area. Furthermore, it has been widely reported that after a first tumor occurrence, the chance of recurrence is statistically enhanced [11]. In fact, the presence of $\mathrm{AK}$ is associated with a greater than 6-fold increase in the risk of developing skin cancers [12]. Although it is difficult to predict the probability that a specific AK lesion will convert to more advanced disease, reports indicate that SCC originate in lesions previously diagnosed as $\mathrm{AK}$, or within a field that contained $\mathrm{AK}$, at frequencies ranging from 65 to $97 \%[13,14]$. It has recently been shown that cutaneous invasive SCC may also directly arise from a proliferation of atypical basaloid cells limited mostly to the epidermal basal layer (AK I) and not limited to the classical pathway of stepwise pro- 
gression from AK I to AK II to AK III as previously believed [15]. This finding suggests that all AK lesions are therefore potentially invasive and tumor advance along adnexal structures might facilitate invasive SCC development from AK I lesions. Notwithstanding the pathway, over the course of 10 years, about $10 \%$ of AK develop into invasive SCC, supporting an estimation of hundreds of thousands of patients constantly developing potentially metastasizing skin tumors $[16,17]$. The latter, however, is a disease stage which is evidently not successfully treatable and should therefore be avoided at all costs.

The basic event in photocarcinogenesis is the induction of DNA damage by UV radiation. UVA and UVB induce primarily two types of DNA lesions - cyclobutane pyrimidine dimers (CPD) and (6-4) photoproducts. Induction of DNA lesions is a common event, occurring upon exposure to rather low, nonerythematogenic doses of UVB exposure. The majority of these lesions are usually removed by nucleotide excision repair (NER), a complex repair process involving over 20 proteins [18]. The efficacy and the importance of NER are best shown by the disease xeroderma pigmentosum (XP). Owing to genetic mutations in specific components of NER, XP patients are severely impaired in their DNA repair capacity and, as a consequence, experience a dramatically (1,000-fold) increased incidence of skin cancer at early ages [19]. Mutations in the tumor suppressor gene p53 are believed to be a very early if not initial event in skin carcinogenesis [20]. In premalignant lesions and in situ carcinomas, p53 overexpression is not exclusively restricted to neoplastic cells but frequently affects the histologically and clinically normal-appearing keratinocytes adjacent to $\mathrm{p} 53$-positive neoplasms or present in dysplastic areas [21]. Mutations of the p53 gene occur early in the sequential development of chronically sun-damaged skin, AK and SCC, strongly supporting an important role for p53 in UVinduced skin carcinogenesis. The p53 gene is essential in maintaining genomic integrity by blocking DNA replication in response to DNA damage from exposure to agents like UV light. In the presence of an intact p53 gene, cells with extensive damage are blocked from entering the cell cycle and instead undergo apoptosis. In this regard it should be mentioned that visible light as well as nearinfrared radiation can also exert biological effects on human skin. Whether these are of relevance for photocarcinogenesis, however, is currently not known.

Of note, UV radiation-induced DNA damage also causes immunosuppressive effects which are thought to additionally contribute to the development of skin cancer $[22,23]$.

New Strategies in the Prevention of Actinic Keratosis: A Critical Review

\section{Prevention by Sunscreens}

Ideally, any intervention aimed at preventing and reversing the photo-induced changes should be able to reverse the initial molecular changes caused by UV damage - the very same changes that define the field of cancerization. In view of the depth of damage induced by UV exposure of the skin, avoidance of sun exposure by staying out of the sun during the peak hours of UV emission should be stressed as the primary step in preventing UVinduced damage. The use of appropriate protective clothing reaffirms preventive measures that should be promoted. When UV exposure cannot be limited, sunscreens can provide protection against damage caused by UV exposure. In an Australian study with 588 patients, the use of sunscreen with a sun protection factor (SPF) of 17 during one summer prevented the development of AK and hastened the remission of existing ones [24]. It is now generally believed that regular use of sunscreens reduces the incidence of AK [24] and new AK lesions [25] and aids in the remission of existing ones in immune-competent subjects.

Although the American Academy of Dermatology recommends the generous application of a 'sunscreen with SPF of at least 30' to reduce the incidence of UV-related skin cancers, there is evidence that sunscreens with SPF $>50$ provide additional benefit. Accordingly, sunscreens with high SPF (SPF $\geq 70$ ), when applied by consumers at typically used amounts, may also provide benefit in ultraviolet protection by delivering an actual SPF that meets the minimum SPF levels recommended for skin cancer and photodamage prevention [26]. In contrast, sunscreens with SPF 30 or 50 may not produce sufficient protection at actual consumer usage levels which is generally lower than the $2 \mathrm{mg} \cdot \mathrm{cm}^{-2}$ amount that is recommended. In fact, an increasing number of studies suggest that the actual SPF present on the skin of consumers may be as low as $25 \%$ of the labeled SPF [27].

In other words, a sunscreen of SPF 50 would provide, under real consumer use conditions, an SPF of 12.5, which would be lower than the minimum SPF of $15 \mathrm{rec}-$ ommended by the Food and Drug Administration (USA) for the achievement of the prevention of NMSC. In selected cases, the very high SPF (up to 100) sunscreens are feasible today due to advances in formulation technology that have not only achieved stable formulations but also with galenic characteristics that aid consumer compliance. In addition, sunscreens with very high SPF may be of benefit for specific subgroups with greater susceptibility towards UV radiation-induced carcinogenesis. One 
such group is organ transplant recipients as they are highly susceptible to developing NMSC such as AK, invasive SCC and basal cell carcinoma (BCC). In 2009, a study with 120 immunocompromised organ transplant recipients demonstrated that regular use of sunscreen with SPF $>50$ prevented the development of further $\mathrm{AK}$, invasive SCC and, to a lesser degree, BCC in these patients [28]. All patients were equally informed on sun protection measures, but 60 of these were provided with a free broadspectrum study sunscreen (SPF $>50$, high UVA absorption) for daily application of $2 \mathrm{mg} \cdot \mathrm{cm}^{-2}$ to the head, neck, forearms, and hands. After 24 months, 42 of the 120 patients had developed 82 new AK ( -102 sunscreen group vs. +82 control group), 8 new invasive SCC ( 0 vs. 8$)$ and 11 new BCC (2 vs. 9). In spite of equal numbers of AK at baseline, a marked difference in favor of the intent-totreat sunscreen group was recorded after 2 years, and the lesion count was significantly lower compared to the initial visit.

Apart from the harmful effects of solar radiation a limited UV exposure is necessary for endogenous vitamin D synthesis in the skin [29]. However, this can be achieved by short-term UV exposures of very limited areas of the skin - in sunny areas like Florida or California but not in Chicago or Northern Europe [30]. Nevertheless, given the carcinogenic risk of UV exposure any further intensive sun exposure or sunbed use should strictly be avoided and a vitamin D deficiency should be treated with oral vitamin D supplementation rather than increased UV exposure.

Although sunscreens provide protection against UVinduced DNA damage and resulting biological consequences, they are completely ineffective once the damage is sustained. More recently, medical devices containing active molecules capable of repairing preexisting DNA damage have therefore been developed for the prevention of AK.

\section{Medical Devices for the Prevention and Reversal of Actinic Damage}

Novel approaches tap into natural defense mechanisms from nonhuman species such as bacteria, which remove UV radiation-induced DNA damage using an enzyme called T4N5 endonuclease $\mathrm{V}$, or marsupials or algae that use an enzyme called photolyase. Although not expressed in human cells, these repair enzymes work equally well when delivered into human cells through unique mechanisms of action. The enzyme T4N5 endonuclease
$\mathrm{V}$ acts by enhancing the NER mechanism that is already present in humans although deficient in XP patients. A topical application of a T4N5 endonuclease V lotion reduced the incidence of skin cancer in chronically UV radiation-exposed mice by enhancing the removal of CPD [31]. The incorporation of these nonhuman repair enzymes into special liposomes was later shown to enable the penetration of these into human cells and, even more importantly, into human skin when applied topically [32]. In 2001 a multicenter double-blinded study in XP patients revealed that the application of a T4N5 endonuclease-containing lotion significantly reduced the incidence of AK within a period of 1 year [33].

Photolyase is a light-activated flavoenzyme that binds specifically to CPD in DNA and repairs them in a reaction triggered by electron transfer from the photo-excited flavin cofactor to the dimer. Stege et al. [34] applied photolyase prepared from Anacystis nidulans encapsulated in a liposome lotion to the irradiated skin of 19 healthy human volunteers. Light-exposed photolyase significantly reduced the number of UVB-induced CPD in the epidermis. After 30 min of exposure to photoreactivating light, $40-45 \%$ of CPD had been removed from the irradiated areas of skin. Furthermore, the topical application of this xenogeneic DNA repair enzyme was able to prevent UVB radiation-induced erythema, keratinocyte apoptosis and, most importantly, immunosuppression in vivo in humans. Of the two DNA repair enzymes, photolyase in a liposomal preparation with photoreactivation restores UVB-induced dipyrimidine dimers faster and more effectively than the topical use of T4 endonuclease $\mathrm{V}$ in a similar preparation. This difference can be attributed to the fact that $\mathrm{T} 4$ endonuclease $\mathrm{V}$ is one player in a concert of multiple NER enzymes. In healthy humans with no deficiency of this repair enzyme system the addition of single enzymes may only result in a limited increase of repair activity. In contrast, since photoreactivation seems not to occur in human skin in the absence of photolyase [35], the topical application of photolyase and photoreactivation transiently provides an additional DNA repair system to human cells. Therefore, CPD can be very effectively removed by the topical application of xenogeneic photolyase, thus protecting human skin from the detrimental effects of UVB irradiation. The use of photolyase in commercially available sunscreens and after sun products, therefore, can form part of sun protection strategies, whereas the use of T4 endonuclease V containing liposomes may be restricted to indications where existing DNA repair is defective [35]. More recently, medical devices containing UV filters in combination with photoly- 
ase have been developed for the prevention of AK. This medical device category of products differs from common sunscreens in that whereas common cosmetic sunscreens are subject to the European Commission recommendation and do not require an external certification, a medical device class II is certified by an independent notified body and fulfills the European requirements of a medical device class II. Some human studies have looked at the use of one such topical cream which combines photolyase enzyme in liposomes with very high SPF UV filters. Of note, in addition to the medical devices mentioned above, sunscreens are commercially available which also contain DNA repair enzymes such as photolyase.

\section{Clinical Evidence}

At least five clinical studies have demonstrated the effect of a topically applied medical device in cream or fluid formulation containing photolyase encapsulated in liposomes and UV filters with very high SPF $(>100)$. A summary of these studies is provided in table 1.

Puviani et al. [36] reported a series of 6 patients with AK lesions treated with the above-mentioned medical device, both as coadjuvant or the only treatment, applied twice daily in cream or fluid formulation for a mean of 1-3 months. Clinical photographs of the skin lesions at baseline and after treatment showed an improvement of the field cancerization, especially of AK lesions.

Another report presented retrospective data regarding the use of the medical device containing photolyase in 8 XP patients treated for at least 12 consecutive months, comparing the rate of new skin lesions (AK, BCC and SCC) during active treatment and during 12 months just before the use of the medical device [37]. New NMSC lesion numbers during the 1-year treatment with the topical cream were 5, 3 and 0 , respectively, in comparison with 14, 6.8 and 3 lesions, respectively, during the 1-year pretreatment period. The use of the topical cream was associated with a $65 \%$ reduction of new AK lesions and with a 56 and $100 \%$ reduction in the incidence of new BCC and SCC lesions, respectively, suggesting that the topical use of photoprotection and DNA repair enzyme could help to decrease the incidence of NMSC in XP [35].

In a third study, 13 patients (11 DNA repair proficient, 2 of whom were XP patients) older than 50 years with an area larger than $3.6 \times 3.6 \mathrm{~cm}$ affected by multiple AK lesions in a sun-exposed skin area were treated for 4 weeks with a medical device with photolyase and high SPF UV

New Strategies in the Prevention of Actinic Keratosis: A Critical Review filters or a sunscreen containing UV filters only - both with an identical SPF. The patients were instructed to apply the cream in the morning and $4 \mathrm{~h}$ later. A clinical evaluation was performed during the treatment, by dermoscopy and reflectance confocal microscopy (CM), and at the beginning and at the end of the treatment by histopathology and at the molecular level using CPD detection and RNA expression arrays. The evaluation showed an improvement in the $\mathrm{AK}$, reaching a histological clearance of $\mathrm{AK}$ in 4 cases and an improvement with the presence of focal AK associated with inflammation in another 3 cases. In contrast, no improvement was noted in the 3 patients who had used the product containing UV filters only. The clinical and dermoscopic evaluation demonstrated a significant improvement of erythema and scaling after 4 weeks of treatment with the medical device compared to the control group treated with UV filters only. Immunohistochemical analysis of biopsy samples before and after treatment showed a decreased expression of p21 in the suprabasal layer and a decreased expression of proliferating cell nuclear antigen proteins in the basal layer [38].

In another publication the same authors evaluated the molecular effects of topical cream on the cutaneous field of cancerization in 7 AK patients [39]. This study was conducted with the same set of patients reported in the study by Puig et al. [38], where only 7 patients participated in this phase of the study. The area assessed for cutaneous field of cancerization was divided into four $0.8 \times$ $0.8 \mathrm{~cm}$ subareas. A $3-\mathrm{mm}$ punch biopsy was obtained from area 1 for histopathological evaluation and another 3-mm punch biopsy was taken from area 2 before starting treatment and preserved for RNA extraction. After 4 weeks of product application, two additional punch biopsies were obtained from area 3 for histopathological examination and from area 4 for additional RNA extraction. Global gene expression analysis was conducted by DNA microarray. Histopathology results were used to classify patients into fast responders and slow partial responders. Overexpression of the CPI-17 gene (2.8-fold increase, $\mathrm{p}=0.039$ ) and the WDR72 gene (1.9-fold increase, $\mathrm{p}=0.040)$ was detected in fast responders. The authors concluded that 1-month treatment with the medical device containing photolyase improved the field of cancerization and restored normal phenotype in at least a subset of samples, as shown by CPI-17 upregulation - a gene involved in normal phenotype recovery [39].

In a longitudinal, observational clinical trial from Brazil, 14 patients ( 8 men and 6 women, aged between 45 and 65 years) with grade I and grade II AK and other cutane- 
Table 1. Summary of clinical studies with a medical device containing DNA repair enzyme photolyase and high SPF sunscreen

\begin{tabular}{|c|c|c|c|c|c|}
\hline Study & Participants & Treatment & Duration & Assessment & Efficacy/findings \\
\hline $\begin{array}{l}\text { Puig [38], } \\
2014\end{array}$ & $\begin{array}{l}\text { M:F 12:1, XP } 2 \text { patients } \\
\text { Mean age: } 72 \text { years } \\
\text { FST I:II:III:IV 1:7:3:2 } \\
\text { AK in area larger than } \\
3.6 \times 3.6 \mathrm{~cm} \text { affected by } \\
\text { multiple AK lesions in } \\
\text { a sun-exposed skin area }\end{array}$ & $\begin{array}{l}\text { Photolyase } \\
\text { encapsulated in } \\
\text { liposomes with } \\
\text { high SPF SS, } \\
\mathrm{n}=9 \\
\text { Control, SS } \\
\text { cream, } \mathrm{n}=3\end{array}$ & 4 weeks & $\begin{array}{l}\text { Clinical dermoscopy } \\
\text { Reflectance CM } \\
\text { Histology } \\
\text { Immunohistochemistry }\end{array}$ & $\begin{array}{l}\text { Improved erythema and scaling }(\mathrm{p}=0.03) \text { in } \\
\text { photolyase-treated group compared to SS } \\
\text { Decreased presence of scaling, detached } \\
\text { corneocytes and polygonal nucleated cells in } \\
\text { the stratum corneum } \\
\text { Histological clearance in } 4 \text { patients and } \\
\text { improvement with focal AK associated with } \\
\text { inflammation in } 3 \text { patients } \\
\text { Decreased p } 21 \text { and PCNA expression in } \\
\text { suprabasal layers }\end{array}$ \\
\hline $\begin{array}{l}\text { Puig-Butille } \\
\text { [39], } 2013\end{array}$ & $\begin{array}{l}\text { M:F 12:1, XP } 2 \text { patients } \\
\text { Mean age: } 72 \text { years } \\
\text { FST I:II:III:IV 1:7:3:2 } \\
\text { AK in area larger than } \\
3.6 \times 3.6 \mathrm{~cm} \text { affected by } \\
\text { multiple AK lesions in } \\
\text { a sun-exposed skin area }\end{array}$ & $\begin{array}{l}\text { Photolyase } \\
\text { encapsulated in } \\
\text { liposomes with } \\
\text { high SPF SS, } \\
\mathrm{n}=7 \\
\text { Control, SS } \\
\text { cream, } \mathrm{n}=3\end{array}$ & $\begin{array}{l}4 \text { weeks, } \\
2 \times / \text { day }\end{array}$ & $\begin{array}{l}\text { RNA extracted from } \\
\text { 3-mm punch biopsies } \\
\text { and histopathological } \\
\text { evaluation from } 2 \text { areas } \\
\text { before and after } \\
\text { treatment; global gene } \\
\text { expression analysis by } \\
\text { DNA microarray and } \\
\text { confirmation by RT-PCR }\end{array}$ & $\begin{array}{l}\text { Histopathologically classified patients into } \\
\text { fast responders and slow-partial responders } \\
\text { Overexpression of } C P I-17 \text { gene }(2.8 \text {-fold } \\
\text { increase, } \mathrm{p}=0.039) \text { and } W D R 72 \text { gene }(1.9 \text { - } \\
\text { fold increase, } \mathrm{p}=0.040) \text { in subgroup of fast } \\
\text { responders }\end{array}$ \\
\hline $\begin{array}{l}\text { Puviani [36], } \\
2013\end{array}$ & $\begin{array}{l}6 \text { case reports } \\
\text { All male } \\
\text { Age: } 65-75 \text { years } \\
\text { FST II } \\
\text { Visible AK in face or } \\
\text { on scalp }\end{array}$ & $\begin{array}{l}\text { Photolyase } \\
\text { encapsulated in } \\
\text { liposomes with } \\
\text { high SPF SS as } \\
\text { adjuvant or } \\
\text { single therapy }\end{array}$ & 4-8 weeks & $\begin{array}{l}\text { Clinical assessment with } \\
\text { photodocumentation }\end{array}$ & $\begin{array}{l}\text { The majority of AK lesions clinically } \\
\text { disappeared }\end{array}$ \\
\hline $\begin{array}{l}\text { Guistini [37], } \\
2014\end{array}$ & $\begin{array}{l}8 \text { XP patients } \\
\text { M:F } 3: 5 \\
\text { Mean age: } 55 \text { years } \\
\text { FST II:III } 6: 2\end{array}$ & $\begin{array}{l}\text { Photolyase } \\
\text { encapsulated in } \\
\text { liposomes with } \\
\text { high SPF SS as } \\
\text { only therapy, } \\
\mathrm{n}=8\end{array}$ & 12 months & $\begin{array}{l}\text { Rate of new skin lesions } \\
\text { (AK, BCC and SCC) } \\
\text { during active treatment } \\
\text { with product and during } \\
12 \text { months just before the } \\
\text { use of the product }\end{array}$ & $\begin{array}{l}65 \% \text { reduction in appearance of new } \mathrm{AK} \\
\text { lesions } \\
56 \% \text { and } 100 \% \text { reductions in the incidence of } \\
\text { new BCC and SCC lesions, respectively }\end{array}$ \\
\hline $\begin{array}{l}\text { Rstom [40], } \\
2014\end{array}$ & $\begin{array}{l}14 \text { patients } \\
\text { M:F 8:6 } \\
\text { Age: } 45-65 \text { years } \\
\text { Grade I and grade II } \\
\text { AK and other } \\
\text { cutaneous signs of } \\
\text { actinic damage }\end{array}$ & $\begin{array}{l}\text { Photolyase } \\
\text { encapsulated in } \\
\text { liposomes with } \\
\text { high SPF SS }\end{array}$ & $\begin{array}{l}120 \text { days, } \\
\text { daily } \\
\text { application }\end{array}$ & $\begin{array}{l}\text { AK lesions documented } \\
\text { by clinical photography, } \\
\text { optical polarized light } \\
\text { dermoscopy and CM in } \\
\text { vivo }\end{array}$ & $\begin{array}{l}17 \text { AK, } 14 \text { grade I and } 3 \text { grade II lesions } \\
\text { Of grade I lesions, clinical and dermoscopic } \\
\text { improvement with reduction of erythema } \\
\text { and desquamation in } 9 \text { lesions; } 3 \text { remained } \\
\text { unchanged and } 1 \text { progressed to grade II } \\
\text { Of } 8 \text { AK lesions examined by CM, } 5 \text { were } \\
\text { grade I and } 3 \text { grade II; grade I AK showed } \\
\text { decreased scaling and improved standard } \\
\text { structural epidermal examination; no } \\
\text { improvement was seen of grade II lesions }\end{array}$ \\
\hline
\end{tabular}

FST = Fitzpatrick skin type; SS = sunscreen

ous signs of actinic damage were prospectively studied [40]. After selection the AK lesions were documented through clinical photography, optical polarized light dermoscopy and reflectance CM in vivo. Patients were instructed to apply daily the medical device containing photolyase and sunscreen SPF 100. After 120 days, new clinical photographic documentation, optical polarized light dermoscopy and in vivo CM were carried out. The images obtained before and after treatment were compared. A total of 17 AK lesions, 14 grade I and 3 grade II, were documented with clinical photographs and dermoscopy before and after 120 days of cream use. Of the $14 \mathrm{AK}$ grade I lesions, 9 showed clinical improvement with a reduction of erythema and desquamation in dermoscopic evaluation; 3 remained unchanged and $1 \mathrm{AK}$ lesion evolved into grade II. All 3 grade II AK showed no clinical and dermoscopic improvement after 120 days of cream use. In addition, 8 of these lesions were studied by CM in vivo. Of these, 5 were AK grade I and 3 grade II. All patients with grade I AK showed decreased scaling and improved stan- 


\begin{tabular}{|c|c|c|c|c|}
\hline $\begin{array}{c}\text { Risk } \\
\text { categories }\end{array}$ & Low risk & $\begin{array}{l}\text { Moderate } \\
\text { risk }\end{array}$ & $\begin{array}{l}\text { High } \\
\text { risk }\end{array}$ & $\begin{array}{l}\text { Very } \\
\text { high risk }\end{array}$ \\
\hline $\begin{array}{l}\text { Description of } \\
\text { population }\end{array}$ & $\begin{array}{l}\text { Fitzpatrick skin } \\
\text { type } \geq \text { III } \\
\text { Negative personal } \\
\text { and family history } \\
\text { for NMSC } \\
\text { No risky behavior } \\
\text { (no sunburn } \\
\text { history, no sunbed } \\
\text { use) }\end{array}$ & $\begin{array}{l}\text { Fitzpatrick skin type <III } \\
\text { and/or positive family } \\
\text { History of NMSC } \\
\text { and/or risky behavior } \\
\text { [sunburn history, sunbed } \\
\text { use, outdoor activities } \\
\text { (both work and leisure)] }\end{array}$ & $\begin{array}{l}\text { Presence of AK } \\
\text { History of AK } \\
\text { treatment } \\
\text { Positive history of AK } \\
\text { and/or BCC/SCC } \\
\text { in immunocompetent } \\
\text { subjects } \\
\text { Subjects with clinically } \\
\text { relevant photodamage }\end{array}$ & $\begin{array}{l}\text { Presence of more } \\
\text { than } 10 \mathrm{AK} \text { lesions } \\
\text { with field } \\
\text { cancerization } \\
\text { Organ transplant } \\
\text { recipients } \\
\text { Immunosuppressed } \\
\text { subjects } \\
\text { (iatrogenic, } \\
\text { noniatrogenic) } \\
\text { XP patients }\end{array}$ \\
\hline $\begin{array}{l}\text { Recommenda- } \\
\text { tions for } \\
\text { adjuvant } \\
\text { photoprotection }\end{array}$ & $\begin{array}{l}\text { Photoprotection } \\
\text { in summer } \\
\text { (level II; grade B) }\end{array}$ & $\begin{array}{l}\text { Photoprotection all year } \\
\text { round with SPF }>50 \\
\text { Cosmetic product could } \\
\text { be good } \\
\text { (level II, grade B) }\end{array}$ & \multicolumn{2}{|c|}{$\begin{array}{l}\text { Very high photoprotection and } \\
\text { photorepair action (DNA repair enzymes) } \\
\text { in medical device products all year round } \\
\text { (level Ib, grade A) }\end{array}$} \\
\hline
\end{tabular}

Fig. 1. Adjuvant treatment algorithm. Cosmetic product: this medical device category of products differs from common sunscreens in that whereas common cosmetic sunscreens are subject to the European Commission recommendation and do not require an external certification, a medical device class II is certified by an independent notified body and fulfills the European requirements for a medical device class II. dard epidermal structure. The 3 patients with grade II AK did not show any improvement after 120 days of treatment. The authors concluded that the use of topical cream containing photolyase and sunscreen showed improved results of grade I AK and field cancerization as evaluated by clinical dermoscopy and CM.

\section{Conclusion}

Taken together, there is evidence from the studies mentioned above and listed in table 1 to indicate that the use of medical devices containing the DNA repair enzyme photolyase combined with a very high UV protection is beneficial in patients with AK because it can reduce field cancerization and the occurrence of new AK. The majority of these studies involved small numbers of patients. In fact, a large, controlled, randomized, doubleblinded study in DNA repair-proficient, immunocompetent individuals to show the efficacy of photolyase-containing medical devices in the prevention of $\mathrm{AK}$ and the treatment of field cancerization is currently lacking. The experts, however, acknowledge the fact that such a study, although highly desirable, is extremely difficult to perform given the fact that photocarcinogenesis in humans is a process involving many years. In view of the ongoing and anticipated increase in AK numbers, the group, therefore, proposes an algorithm for its prevention as described in figure 1, balancing the category of evidence available and the strength of recommendation as per the guidelines for developing clinical guidelines according to Shekelle et al. [41], where the category of evidence varies from IA to IV - category IA being the one with most clinical evidence available in the form of meta-analysis of randomized, controlled trials. The strength of recommendation varies from grades $\mathrm{A}$ to $\mathrm{D}$, with grade $\mathrm{A}$ being the strongest level of recommendation which takes into account the category of evidence and other additional factors. Briefly, persons with Fitzpatrick phototype III or higher with no family or personal history of NMSC are at low risk for photodamage. In this population the use of photoprotection during summer is probably sufficient (level of evidence IIb, grade of recommendation B). Persons considered at moderate risk, for example those with phototype I and II, a personal or family history of NMSC or elevated work-related sun exposure, could be recommended the all-year-round use of a high-quality sunscreen product SPF $>50$ with a balanced UVA and UVB protection spectrum (level of evidence IIb, grade of recommendation B). However, persons at high or very high risk should be recommended the year-round use of a medical device that, in addition to very high photoprotec- 
tion (SPF $\geq 100$ ), contains DNA repair enzymes with the potential to actually reverse photo-induced DNA damage. High-risk groups can be defined as persons with AK or recently treated for $\mathrm{AK}$, positive history of $\mathrm{AK}$ or NMSC or clinically relevant photodamage. The veryhigh-risk population, comprising organ transplant recipients, immunosuppressed patients (both iatrogenic and noniatrogenic), XP patients, and patients with 10 or more AK lesions, should be strongly recommended the use of these medical devices that offer more than photoprotection (level of evidence IIa, grade of recommendation A). We consider that in this very-high-risk group of patients the level of recommendation should be rated A, despite lacking a level of evidence Ia, in view of the substantial clinical risk of developing skin cancer. A photoprotection and also photorepair strategy could therefore be considered as mandatory. Very recently, Premi et al. [42] have demonstrated that in melanocytes the generation of CPD could be induced also $>3 \mathrm{~h}$ after UV exposure ('dark' CPD). This mechanism seems to be mediated by the oxidation of melanin, which in turn induces CPD formation in a radiation-independent manner, suggesting that melanin may be a carcinogen as well as being protective against skin cancer. These data further underline the potential relevance and importance of DNA photorepair mechanisms in order to reduce the risk of actinic damage and skin cancer.

\section{Disclosure Statement}

The consensus meeting with all authors of this paper was supported by ISDIN, Barcelona, Spain.

\section{References}

1 Marks R: Epidemiology of non-melanoma skin cancer and solar keratosis in Australia: a tale of self-immolation in Elysian fields. Australas J Dermatol 1997;38:S26- S29.

- Frost CA, Green AC: Epidemiology of solar keratoses. Br J Dermatol 1994;131:455-464.

- 3 Stockfleth E, Terhorst D, Braathen L, et al; Guideline Subcommittee of the European Dermatology Forum: Guidelines for the management of actinic keratosis - update 2011. http://bestpractice.bmj.com/best-practice/ monograph/616/diagnosis/guidelines.html (accessed August 25, 2013).

-4 Schaefer I, Augustin M, Spehr C, Reusch M, Kornek T: Prevalence and risk factors of actinic keratoses in Germany - analysis of multisource data. J Eur Acad Dermatol Venereol 2014;28:309-313.

5 Berman B, Cockerell CJ: Pathobiology of actinic keratosis: ultraviolet-dependent keratinocyte proliferation. J Am Acad Dermatol 2013;68:S10-S19.

-6 Diepgen TL, Brandenburg S, Aberer W, Bauer A, Drexler H, Fartasch M, Malte John, S, Krohn S, Palfner S, Römer W, SchuhmacherStock U, Elsner P: Skin cancer induced by natural UV-radiation as an occupational disease - requirements for its notification and recognition. J Dtsch Dermatol Ges 2014;12:11021106.

7 Schmitt J, Seidler A, Diepgen TL, Bauer A: Occupational UV-light exposure increases the risk for the development of cutaneous squamous cell carcinoma: a systematic review and meta-analysis. Br J Dermatol 2011;164: 291-307.
8 Oppel T, Korting HC: Actinic keratosis: the key event in the evolution from photoaged skin to squamous cell carcinoma; therapy based on pathogenetic and clinical aspects. Skin Pharmacol Physiol 2004;17:67-76.

9 Segen JC: Field cancerization; in Medical Dictionary - The Free Dictionary. McGraw-Hill Concise Dictionary of Modern Medicine. New York, McGraw-Hill, 2002.

10 Braakhuis BJM, Tabor MP, Kummer JA, Leemans CR, Brakenhoff RH: A genetic explanation of Slaughter's concept of field cancerization: evidence and clinical implications. Cancer Res 2003;63:1727-1730.

11 Brennan JA, Mao, L, Hruban, RH, Boyle, JO, Koch, WM, Sidransky D: Molecular assessment of histopathological staging in squamous cell carcinoma of the head and neck. $\mathrm{N}$ Engl J Med 1995;332:429-435.

12 Chen GJ, Feldman SR, Williford PM, Hester EJ, Kiang SH, Gill I, et al: Clinical diagnosis of actinic keratosis identifies an elderly population at high risk of developing skin cancer. Surg Dermatol 2005;31:43-47.

13 Mittelbronn MA, Mullins DL, Ramos-Caro FA, Flowers FP: Frequency of pre-existing actinic keratosis in cutaneous squamous cell carcinoma. Int J Dermatol 1998;37:677-681.

14 Czarnecki D, Meehan CJ, Bruce F, Culjak G: The majority of cutaneous squamous cell carcinomas arise in actinic keratoses. J Cutan Med Surg 2002;6:207-209.

15 Fernández-Figueras MT, Carrato C, Sáenz X, Puig L, Musulen E, Ferrándiz C, Ariza A: Actinic keratosis with atypical basal cells (AK I) is the most common lesion associated with invasive squamous cell carcinoma of the skin. J Eur Acad Dermatol Venereol 2015;29:991-997.
16 Dodson JM, DeSpain J, Hewett JE, Clark DP: Malignant potential of actinic keratoses and the controversy over treatment. A patientoriented perspective. Arch Dermatol 1991; 127:1029-1031.

17 Glogau RG: The risk of progression to invasive disease. J Am Acad Dermatol 2000;42: 23-24.

18 de Laat WL, Jaspers NGJ, Hoeijmakers JHJ: Molecular mechanism of nucleotide excision repair. Genes Dev 1999;13:768-785.

19 Kraemer KH, Levy DD, Parris CN, Gozukara EM, Moriwaki S, Adelberg S, Seidman MM: Xeroderma pigmentosum and related disorders: examining the linkage between defective DNA repair and cancer. J Invest Dermatol 1994;103(suppl 5):96S-101S.

20 Ziegler A, Jonason AS, Leffell DJ, Simon JA, Sharma HW, Kimmelman J, Remington L, Jacks T, Brash DE: Sunburn and p53 in the onset of skin cancer. Nature 1994;372:773776.

21 Raybaud-Diogène $H$, Tétu B, Morency R, Fortin A, Monteil RA: p53 overexpression in head and neck squamous cell carcinoma: review of the literature. Eur J Cancer B Oral Oncol 1996;32B:143-149.

22 Schwarz T, Schwarz A: DNA repair and cytokine responses. J Investig Dermatol Symp Proc 2009; 14:63-66.

23 Aubin F: Mechanisms involved in ultraviolet light-induced immunosuppression. Eur J Dermatol 2003;13:515-523.

24 Thompson SC, Jolley D, Marks R: Reduction of solar keratoses by regular sunscreen use. $\mathrm{N}$ Engl J Med 1993;329:1147-1151. 
25 Naylor MF, Boyd A, Smith DW, Cameron GS, Hubbard D, Neldner KH: High sun protection factor sunscreens in the suppression of actinic neoplasia. Arch Dermatol 1995;131: 170-175.

26 Ou-Yang H, Stanfield J, Cole C, Appa Y, Rigel D: High-SPF sunscreens (SPF $\geq 70$ ) may provide ultraviolet protection above minimal recommended levels by adequately compensating for lower sunscreen user application amounts. J Am Acad Dermatol 2012;67: 1220-1227.

-27 Neale R, Williams G, Green A: Application patterns among participants randomized to daily sunscreen use in a skin cancer prevention trial. Arch Dermatol 2002;138:13191325.

28 Ulrich C, Jürgensen JS, Degen A, Hackethal M, Ulrich M, Patel MJ, Eberle J, Terhorst D, Sterry W, Stockfleth E: Prevention of nonmelanoma skin cancer in organ transplant patients by regular use of a sunscreen: a 24 months, prospective, case-control study. $\mathrm{Br} J$ Dermatol 2009;161(suppl 3):78-84.

29 Holick MF: Sunlight, ultraviolet radiation, vitamin D and skin cancer: how much sunlight do we need? Adv Exp Med Biol 2014;810:116.

30 Terushkin V, Bender A, Psaty EL, Engelsen O, Wang SQ, Halpern AC: Estimated equivalency of vitamin $\mathrm{D}$ production from natural sun exposure versus oral vitamin D supplementation across seasons at two US latitudes. J Am Acad Dermatol 2010;62:929.e1-e9.
Yarosh D, Alas LG, Yee V, Oberyszyn A, Kibitel JT, Mitchell D, Rosenstein R, Spinowitz A: Pyrimidine dimer removal enhanced by DNA repair liposomes reduces the incidence of UV skin cancer in mice. Cancer Res 1992;52: 4227-4231.

32 Yarosh D, Bucana C, Cox P, Alas L, Kibite, J, Kripke M: Localization of liposomes containing a DNA repair enzyme in murine skin. J Invest Dermatol 1994;104:461-468.

33 Yarosh D, Klein J, O’Connor A, Hawk J, Rafal E, Wolf P: Effect of topically applied T4 endonuclease $\mathrm{V}$ in liposomes on skin cancer in xeroderma pigmentosum: a randomised study. Lancet 2001;357:926-929.

-34 Stege H, Roza L, Vink AA, Grewe M, Ruzicka $\mathrm{T}$, et al: Enzyme plus light therapy to repair DNA damage in ultraviolet-B-irradiated human skin. Proc Natl Acad Sci USA 2000;97: 1790-1795.

35 Stege H: Effect of xenogenic repair enzymes on photoimmunology and photocarcinogenesis. J Photochem Photobiol B 2001;65:105108.

36 Puviani M, Barcella A, Milani M: Eryfotona AK-NMSC in the treatment of cancerization field in patients with actinic keratosis or nonmelanoma skin cancer: a report of six cases. G Ital Dermatol Venereol 2013;148(suppl 2):1-6.
Giustini S, Miraglia E, Berardesca E, Milani $\mathrm{M}$, Calvieri S: Preventive long-term effects of a topical film-forming medical device with ultra-high UV protection filters and DNA repair enzyme in xeroderma pigmentosum: a retrospective study of eight cases. Case Rep Dermatol 2014;6:222-226.

38 Puig S, Puig-Butillé JA, Díaz MA, Trullas C, Malvehy J: Field cancerisation improvement with topical application of a film-forming medical device containing photolyase and UV filters in patients with actinic keratosis, a pilot study. J Clin Exp Derm 2014;5:1-7.

39 Puig-Butille JM, Malvehy J, Potrony M, Trullas C, Joaquin Dopazo J, Puig S: Role of CPI17 in restoring skin homoeostasis in cutaneous field of cancerization: effects of topical application of a film-forming medical device containing photolyase and UV filters. Exp Dermatol 2013;22:482-501.

40 Rstom SA, Martinez B, Abdalla Z, Rezze GG, Paschoal FM: Avaliação da ação de creme contendo fotolíase em lipossomas e filtro solar FPS 100 na queratose actínica da face: estudo clínico, dermatoscópico e por microscopia confocal. Surg Cosmet Dermatol 2014;6: 226-231.

41 Shekelle PG, Woolf SH, Eccles M, Grimshaw $\mathrm{J}$ : Developing clinical guidelines. West J Med 1999;170:348-351.

-42 Premi S, Wallisch S, Mano CM, Weiner AB, Bacchiocchi A, Wakamatsu K, Bechara EJ, Halaban R, Douki T, Brash DE: Chemiexcitation of melanin derivatives induces DNA photoproducts long after UV exposure. Science $2015 ; 347: 842-847$. 